УДК 37.015.3:159.922.8

Сочинська Руслана

здобувач вищого освітнього ступеня «Магістр», спеціальності «Психологія»

Рівненського державного гуманітарного університету

ORCID iD: 0000-0001-9176-7466

DOI https://doi.org/10.35619/prap_rv.vi13.135

\title{
ЕМПІРИЧНЕ ВИВЧЕННЯ ПСИХОЛОГІЧНИХ ОСОБЛИВОСТЕЙ РОЗВИТКУ ТВОРЧОГО ПОТЕНЦАЛУ У ПІДЛІТКІВ
}

Анотація. Стаття присвячена аналізу проблеми розвитку творчого потенціалу у підлітковому вічі. В даній статті проаналізовано емпіричні дані дослідження творчого потенціалу підлітків, також досліджували вплив гендерного показника на розвиток творчості. У наш час глибше усвідомлюється те, щзо саме творчість є найважливішою складовою життя особистості взагалі та їі професійного успіху зокрема.

Особистість розкривається через свою творчість, тобто вона володіє певними можливостями (потенціями), щз становлять ї здатність до творчості. Нашому суспільству потрібна більш творча та активна молодь, яка матиме високий рівень інтелектуального та творчого потенціалу, зможе швидко адаптуватися до умов життя та орієнтуватися у швидкому інформаційному полі, до самостійного, творчого рімення саморозвитку проблеми.

Одним із найважливіших завдань психологічної науки на сучасному етапі розвитку $\epsilon$ вирішення проблеми формування творчої особистості, адже формування у людей творчого способу мислення $\epsilon$ сочіальною необхідністю. Нові умови $i$ перспективи розвитку суспільства, загальні тенденції науково-технічного й економічного прогресу висувають все нові й нові вимоги до підготовки підростаючого покоління, щэо стане в майбутньому запорукою успішного існування людської спільноти.

Ключові слова: творчий потенціал, новоутворення, підліток, почуття дорослості, креативність, розумові прочеси, оригінальність, творчість.

Постановка проблеми. Творчий потенціал - це динамічна структура, що включає комплекс творчих задатків, які проявляються у творчій активності особистості і обумовлена креативністю (Овсянецька, 2004, с. 141). Завдання яке ми ставимо досліджуючи цю тему, полягає у оновленні емпіричних даних, дослідженні творчого потенціалу саме 3 практичної сторони.

Творчий потенціал - тема що вивчається уже протягом тривалого часу та багатьма дослідниками. Кожен із яких з акцентував увагу на своїх ідеях та результатах досліджень, додав своє бачення у загальне розуміння даної теми, також розглядається і вплив різних чинників та факторів на розвиток творчого потенціалу, зокрема таких як вік, стать, соціальне оточення, рівень розумового розвитку, духовного та морального розвитку.

Проте з плином часу подібні дослідження варто проводити заново, перевіряти результати 3 минулими, адже наше суспільство усе більше технологізується, що безумовно також має вплив на загальний розвиток особистості та ії творчого потенціалу зокрема.

Аналіз останніх досліджень 3 проблеми. Ця проблема знайшла своє відображення у працях таких вчених, як Ананьєв, Асеєв, Матюшкін, Муканов, Пономарьов, Рубінштейн, Узнадзе, Степанов, Варламова, Ткач та інші. Вони розкривають саме поняття «творчий потенціал особистості», розглядаючи його на рівні вивчення потенційних і актуальних характеристик людини. Основна ідея у працях згаданих вчених полягає в тому, що творчий потенціал інтерпретується як категорійна форма творчої активності особистості. 
На сучасному етапі проблема творчого потенціалу розкривається в дослідженнях Богоявленської, Е. де Боно, Брушлінського, Волкова, Глотової, Коваленко, Лука, Матюшкіна, Моляко, Савенкова, Симоненко, Хорошуна, Яковлєвої та інших. Особлива увага приділяється виокремленню сутнісних характеристик творчого потенціалу особистості, розглядається структура та взаємозв'язок між основними складовими компонентами, принципами формування та розвитку.

Мета статті - дослідити рівень розвитку творчого потенціалу підлітків, проаналізувати чи актуальним є гендерний показник і його вплив на розвиток творчого потенціалу у дитини.

Виклад основного матеріалу. Підлітковий вік - переломний, критичний, перехідний. На даному етапі люди «вростають» у культуру, дух епохи, в якій підлітки існують. Вони переживають своєрідне друге народження і в його ході набувають нове «я» - головне на той момент новоутворення. В психології це вважається бурхливим, різким і навіть кризовим перебігом. У ньому і виражається перший етап підліткового періоду. Наступна ступінь характеризується плавним, поступовим і повільним ростом, в ході якого молоді люди долучаються до дорослого життя, але не зазнають серйозних і глибоких зрушень у своїй особистості. А третій етап передбачає формування свого «я», його «ограновування». I супутнє всього цього самовиховання, протікає через внутрішні кризи, переживання і тривоги (Шопіна, 2012, с. 101).

Творчість означає насамперед особливий склад розуму, особливу якість розумових процесів. При цьому встановлено, що ніяке абстрактне пізнання не може бути продуктивним у повному відриві від чуттєвого. Важливе значення в процесі творчості - у будь-якій галузі діяльності - мають уява, інтуїція, неусвідомлювані компоненти розумової активності. Деякі дослідники звертали увагу на те, що народження нової ідеї пов’язане 3 «бічним» мисленням, тобто досягається ніби зненацька, саме собою (Шопіна, 2014, с. 80).

Креативність - одна 3 найважливіших характеристик обдарованості. Виявлено, що 3 віком розвиток креативності проходить як мінімум дві фази (Богоявленська, Виготський, Дружинін, Олехнович, Шумакова, Юркевич). Перша фаза. Розвивається «первинна» креативність як загальна творча здатність, неспеціалізована до якої-небудь сфери життєдіяльності. Сензитивний період цього процесу - 3-5 років, де виявляється у цей час літературна й художня творчість дітей. Друга фаза. У віці 13-20 років виникає «спеціалізована» креативність, тобто здатність до творчості в певній сфері діяльності як доповнення й альтернатива «первинної», недиференційованої креативності. На цьому етапі особливої значимості набуває підтримка родини й однолітків. Ця креативність, як відзначає М. О. Олехнович, стосується певного типу мислення, що поступово формується в ході розвитку особистості. Друга фаза у багатьох суб’єктів закінчується відкиданням наслідування й переходом до оригінальної творчості.

Для емпіричного дослідження даної теми, нами було обрано три методики: «Потреба в досягненні» Орлова, Шкуркіна, Орлова, «Діагностика невербальної креативності» Торенса та «Творчий потенціал» Рогова.

Тест «Потреба в досягненні» Орлова, Шкуркіна, Орлова містить твердження, які диференціюють людей двох протилежних груп: 3 високим і низьким рівнями потреби у досягненнях. Початковий перелік пунктів складався таким чином, щоб в них побічно відбивалися індивідуальні особливості людини, орієнтовані на досягнення. В результаті було відібрано 22 твердження, що мають високу валідність і добре диференціюють випробуваних двох полярних груп з високим і низьким рівнем потреби в досягненні.

Тест «Діагностика невербальної креативності» Торенса представляє собою 12 субтестів, згрупованих в три батареї. Ми обрали модифіковану Вороніним версію тесту. Пропонований варіант тесту Торренса представляє собою набір картинок з деяким набором елементів (ліній), використовуючи які піддослідним необхідно домалювати картинку до деякого осмисленого зображення. В даному варіанті тесту використовується 6 картинок, обраних з 10 оригінальних. На думку Вороніна, дані картинки не дублюють за своїми вихідним елементам один одного і дають найбільш надійні результати. За допомогою атласа 
типових малюнків ми визначаємо рівень оригінальності малюнків, присвоюючи певний бал для кожного, потім за формулою виводимо загальну оцінку для кожного досліджуваного. Найвищий рівнь оріганьльності та креативності буде у досліджуваних 3 одним балом, середній - пів бала.

Методика «Творчий потенціал» Рогова дозволяє визначити самооцінку особистісних якостей або частоту їх прояву, які й характеризують рівень розвитку творчого потенціалу особистості. Методика орієнтована на самооцінку досліджуваним певних якостей та процесів. Стимульний матеріал складається із 18 запитань, які пропонують досліджуваному оцінити наскільки на його думку у нього виражена та чи інша якість саме для нього. Оцінка відбувається по дев'ятибальній шкалі. Для прикладу серед запитань пропонується оцінити свою рішучість, критичність у висловлюваннях, енергійність та наполегливість, оптимістичність чи наявність хорошого настрою.

Дослідження проводись серед вибірки підлітків віком 13-15 років, що $є$ учнями Дубенської ЗОШ I-III ступенів, загальна кількість яких 48 осіб, 25 з яких хлопчики, 23 дівчата. Така вибірка досліджуваних підібрана з метою подальшого порівняння результатів за гендерним показником.

Проводячи оцінку потреби у досягненні підлітків за методикою «Потреба в досягненні» Орлова, Шкуркіна, Орлова, що завдяки своїм питанням дозволяє визначити рівень вираженості цієї потреби, ми отримали такі результати:

- високий рівень потреби у досягненні 8 досліджуваних, 4 з яких дівчата, 4 хлопці;

- вище середнього рівня у 11 підлітків, 7 із них - хлопці і 4 дівчинка;

- середній рівень потреби у досягнені виявили у 22 досліджуваних, серед них 13 хлопчиків та 9 дівчат;

- нище середнього рівня потреби у досягнені було виявлено у 6 дівчат і 1 хлопчика.

3 даних результатів ми бачимо, що потреба у досягненні в підлітковому віці є досить високою, оскільки показники тестування у більшої частини досліджуваних знаходяться на середньому та вище середнього, лише кілька учасників різняться високим (8 досліджуваних) та низьким (7 досліджувані) рівнями і фактично не відрізняються за гендерним показником, тобто високі результати як у хлопчиків, так і в дівчат.

Наступна методика «Діагностика невербальної креативності» Торенса модифікована Вороніним дозволяє оцінити рівень креативності досліджуваних за допомогою шести картинок, які потрібно завершити.

Інтерпретувавши результати дослідження ми бачимо такі результати:

- досліджуваних із найвищим рівнем оригінальності виявилось троє, дві дівчинки та один хлопчик;

- досліджуваних, чий рівень креативності варіюється від 0,8 до 0,9 - що є досить високим рівнем було десять, п'ять хлопчиків та п'ять дівчаток;

- досліджуваних із рівнем від 0,6 до 0,7 , що $\epsilon$ середнім показником рівня креативності виявилось дев'ять, четверо хлопців і п'ять дівчат;

- досліджуваних із рівнем від 0,4 до 0,5, що означає нище середнього рівня було одинадцять, п'ять хлопців та шість дівчат;

- $\quad$ досліджуваних з іншими показниками, що вважаються зачатками креативності виявили тринадцять, сім дівчат і шість хлопців.

Також для порівняння результатів нами була використана методика «Творчий потенціал» Рогова, що дозволяє визначити самооцінку особистісних якостей або частоту їх прояву, які й характеризують рівень розвитку творчого потенціалу особистості. Ця методика своїм змістом спрямован саме на самооцінку досліджуваними наявності у себе тих чи інших рис або якостей.

3 отриманих результатів ми бачимо такі показники:

- дуже високим рівнем творчого потенціалу наділені 15 досліджуваних, серед них 9 дівчат та 6 хлопці; 
- високим рівнем творчого потенціалу наділені ще 8 досліджувані, серед яких 6 хлопці і 2 дівчина;

- вище середнього рівня творчим потенціалом наділені 14 досліджуваних: 5 дівчинки та 9 хлопців;

хлопці;

- середнім рівнем творчого потенціалу наділені 6 осіб, серед них 4 дівчини та 2

- нижче середнього рівня творчого потенціалу мають ще 5 досліджуваних: 3 дівчинка та 2 хлопчиків.

Отже, результати даного тестування в цілому підтверджують результати двох попередніх. Загальний рівень розвитку творчого потенціалу досліджуваних підлітків за результатами проведених методик має досить хороші результати, також можна зауважити $\mathrm{i}$ те, що результати практично рівні у співвідношенні між хлопцями та дівчатами. Хоча, особливістю є бальні оцінки, якщо у дівчаток, за результатами може бути більше вищих балів, то хлопчики займають середні і вище середніх позиції, чим у загальних підрахунках зрівнюють результати.

Висновки і перспективи подальших розвідок. Активний розвиток та формування творчого потенціалу переважно відбувається у підлітковий період, під впливом багатьох чинників таких наприклад як самосвідомість, самореалізація, розвиток спонукальної та пізнавальної сфер, самоствердження і самовдосконалення.

Творчий потенціал - це складна система психогенетичних та психологічних якостей, інтегральна цілісність природних і соціальних сил людини, сукупність здібностей, можливостей та властивостей до здійснення творчої діяльності, продукування творчих стратегій і тактик у даному процесі, які дозволяють знаходити унікальне, принципово нове рішення проблем, а також забезпечення суб'єктивної потреби особистості у творчій самореалізації і саморозвитку. Творчий потенціал особистості $\epsilon$ певним ядром його внутрішніх сил, що допомагають йому самореалізуватися.

Методики були підібрані не випадково, кожна із них охоплює одну із граней оцінки творчого потенціалу підлітків, що дає нам можливість усебічно, більш об'єктивно дослідити дане питання. Перша методика «Потреба в досягненні» дозволяє оцінити внутрішню мотивацію та інтереси підлітків, тобто тут може матись на увазі не лише творчість, а й інші сфери, але в даному контексті ми оцінюємо саме потребу бути творчо реалізованим. Наступний тест «Діагостика невербальної креативності» акцентує увагу на оригінальності та унікальності зображень. Креативність, як відомо повинна бути розвинена на високому рівні у творчих особистостей, і ми оцінюємо іiі саме такою методикою щоб побачити наскільки оригінальними є образи, котрі зображували досліджувані. Остання ж, дозволяє критично оцінити свій творчий потенціал, тут важливим є самооцінка та її об'єктивність. Тобто наші результати базуються на комплексному досліджені.

Варто зауважити, що результати досліджень носять досить таки позитивний характер, проте ніколи не варто зупинятись на досягнутому. Ми вважаємо, що розвивати творчі задатки у кожному можна надалі, для цього було створено програму розвитку, результати якої сподіваємось будуть позитивними.

\section{СПИСОК ПОСИЛАНЬ}

Овсянецька, Л. (2004). Творчий потенціал людини: соціально-психологічна парадигма. Соиіальна психологія, 2, 140-145.

Шопіна, М. (2012). Психологічні особливості розвитку творчого потенціалу у підлітковому віці. Вісник НТУУ "КПІ". Філософія. Психологія. Педагогіка, 2, 101-107.

Шопіна, М. (2014). Творчий потенціал як чинник розвитку соціальної активності підлітків. Вісник НТУУ "КПI". Філософія. Психологія. Педагогіка, 3, 78-81. 


\title{
REFERENCES
}

Ovsianetska, L. (2004). Tvorchyi potentsial liudyny: sotsialno-psykholohichna paradyhma [Human creative potential: a socio-psychological paradigm]. Sotsialna psykholohiia, 2, 140-145. [in Ukrainian].

Shopina, M. (2012). Psykholohichni osoblyvosti rozvytku tvorchoho potentsialu u pidlitkovomu vitsi [Psychological features of the development of creative potential in adolescence]. Visnyk NTUU "KPI". Filosofiia. Psykholohiia. Pedahohika, 2, 101-107. [in Ukrainian].

Shopina, M. (2014). Tvorchyi potentsial yak chynnyk rozvytku sotsialnoi aktyvnosti pidlitkiv [Creative potential as a factor in the development of adolescent social activit]. Visnyk NTUU "KPI". Filosofiia. Psykholohiia. Pedahohika, 3, 78-81. [in Ukrainian].

\section{EMPIRICAL STUDY OF PSYCHOLOGICAL DEVELOPMENT FEATURES THE CREATIVE POTENTIAL IN TEENS}

\author{
Ruslana Sochinska \\ graduate student, specialty "Psychology" \\ Rivne State University of the Humanities \\ ORCID iD: 0000-0001-9176-7466 \\ DOI https://doi.org/10.35619/prap_rv.vi13.135
}

\begin{abstract}
The article is devoted to the analysis of the problem of creative potential development in adolescence. This article analyzes the empirical data from a study of adolescents' creative potential and also examined the impact of gender on creativity.

Creative potential is a dynamic structure that includes a set of creative impulses that are manifested in the creative activity of the individual and are conditioned by creativity. The psychological essence of the creative potential of the individual can be defined through the following components: creative ability, creativity, creative activity.

Our society needs more creative and active youth who will have a high level of intellectual and creative potential, will be able to adapt quickly to the living conditions and to navigate in a fast-paced information field, to independent, creative solution of self-development problems.

One of the most important tasks of psychological science at the present stage of development is to solve the problem of forming a creative personality, because the formation of creative thinking of people is a social necessity. New conditions and prospects for the development of society, the general tendencies of scientific, technical and economic progress make ever more new requirements for the preparation of the younger generation, which will become in the future a guarantee for the successful existence of the human community.
\end{abstract}

Key words: creative potential, neoplasms, teenagers, feelings of adulthood, creativity, thought processes, originality.

Стаття надійшла до редакиії 21.10.2019 p. 